\title{
Pulmonary changes in congenital heart disease with Down's syndrome: their significance as a cause of postoperative respiratory failure
}

\author{
SHIGEO YAMAKI, TOGO HORIUCHI, TOHRU TAKAHASHI
}

From the Department of Thoracic and Cardiovascular Surgery, Tohoku University School of Medicine and the Department of Pathology, the Research Institute for Tuberculosis and Cancer, Tohoku University, Sendai, Japan

ABSTRACT Biopsy or necropsy specimens of lung from 28 patients with congenital heart disease and Down's syndrome were studied to establish the cause of the postoperative respiratory failure often seen in such cases. Changes in lungs seen after operation included interstitial emphysema and overdistension of peripheral air spaces, associated with hypoplastic alveoli and deficient elastic fibres in the alveolar wall. In specimens taken before operation alveolar hypoplasia was common but interstitial emphysema or overdistension of lower airways was found only rarely. Findings suggest that alveolar hypoplasia is characteristic of Down's syndrome and that distension of peripheral air spaces or interstitial emphysema was due to artificial inflation of the lung during surgery. The severity of the lesions correlated significantly with the duration of artificial respiration and with the severity of the respiratory failure. Hypoplastic lung tissue in patients with Down's syndrome appears to be more susceptible to mechanical stress, and this is likely to be the cause of postoperative respiratory failure.

Respiratory problems after heart surgery are often seen in cases of congenital heart disease complicating Down's syndrome. In such cases the lung appears to be susceptible to hyperinflation and interstitial emphysema during anaesthesia, and this appears to have a close bearing on the subsequent development of respiratory failure. We therefore studied the histology of the lungs in patients with Down's syndrome and congenital heart disease and compared it with that in patients suffering from congenital heart disease alone. The findings were correlated with the degree of postoperative respiratory failure.

\section{Patients and methods}

Between 1974 and 1983 lung tissue was obtained at operation or necropsy from a total of 28 patients with congenital heart disease and Down's syndrome (table 1). Cardiac repair was performed in 24 , four

Address for reprint requests: Dr Shigeo Yamaki, Department of Thoracic and Cardiovascular Surgery, Tohoku University School of Medicine, Seiryomachi, Sendai, Miyagi, Japan 980.

Accepted 23 November 1984 of whom died shortly after operation. Of the four not undergoing cardiac repair, two died before operation could be performed and the two others underwent thoracotomy for lung biopsy alone.

The age of the patients ranged from 3 months to 10 years with a mean of 2 years, 4 months. As lung tissue grows and transforms rapidly in the early postnatal period' patients aged under 2 months were excluded from the analysis.

Eleven patients had an uncomplicated ventricular septal defect, seven a ventricular septal defect complicated by a patent ductus arteriosus, eight a patent ductus arteriosus, and two an endocardial cushion defect. Control material consisted of samples of lung tissue from 24 patients with congenital heart disease but without Down's syndrome (table 2). Specimens were obtained from 19 by biopsy during surgery and from the remaining five at necropsy after operative death. The age of these patients ranged from 3 months to 6 years, 8 months, with a mean of 1 year, 9 months. Twelve had a ventricular septal defect, eight a complete transposition of the great arteries, three patent ductus arteriosus, and one a ventricular septal defect, patent ductus arteriosus, and atrial septal defect. Twenty seven of the patients with 
Pulmonary changes in congenital heart disease with Down's syndrome

Table 1 Details of patients with congenital heart disease and Down's syndrome

\begin{tabular}{|c|c|c|c|c|c|c|c|c|c|c|}
\hline \multirow{2}{*}{$\begin{array}{l}\text { Case } \\
\text { No }\end{array}$} & \multirow{2}{*}{$\begin{array}{l}\text { Age } \\
\text { (years } \\
\text { and } \\
\text { months) }\end{array}$} & \multirow{2}{*}{$\begin{array}{l}\text { Cardiac } \\
\text { disease }\end{array}$} & \multirow{2}{*}{$\begin{array}{l}\text { Pulmonary } \\
\text { artery } \\
\text { pressure } \\
\text { (mean) } \\
(\mathrm{mm} \mathrm{Hg})\end{array}$} & \multicolumn{4}{|l|}{ Grades* } & \multirow{2}{*}{$\begin{array}{l}\text { Histological } \\
\text { index }\end{array}$} & \multirow{2}{*}{$\begin{array}{l}\text { Duration of } \\
\text { artificial } \\
\text { respiration } \\
\text { (hours) }\end{array}$} & \multirow{2}{*}{$\begin{array}{l}\text { Lung histology } \\
\text { before or after } \\
\text { operation }\end{array}$} \\
\hline & & & & $\begin{array}{l}\text { Interstitial } \\
\text { emphysema }\end{array}$ & $\begin{array}{l}\text { Overdistension } \\
\text { of air spaces }\end{array}$ & $\begin{array}{l}\text { Alveolar } \\
\text { hypoplasia }\end{array}$ & $\begin{array}{l}\text { Alveloar } \\
\text { septitis }\end{array}$ & & & \\
\hline $\begin{array}{r}1 \\
2 \\
3 \\
4 \\
5 \\
6 \\
7 \\
8 \\
9 \\
10 \\
11 \\
12 \\
13\end{array}$ & $\begin{array}{lr}2, & 1 \\
4, & 11 \\
2, & 6 \\
& 11 \\
1, & 6 \\
2, & 3 \\
1, & 4 \\
1 & \\
1, & 3 \\
1 & \\
2 & \\
& 9 \\
& 9\end{array}$ & $\begin{array}{l}\text { VSD } \\
\text { PDA } \\
\text { VSD } \\
\text { VSD } \\
\text { VSD + PDA } \\
\text { PDA } \\
\text { PDA } \\
\text { VSD + PDA } \\
\text { VSD + PDA } \\
\text { PDA } \\
\text { VSD } \\
\text { PDA + PDA } \\
\text { VSD + PDA }\end{array}$ & $\begin{array}{l}88 / 45(65) \\
75 / 56(60) \\
75 / 50(60) \\
75 / 20(35) \\
80 / 30(50) \\
75 / 25(52) \\
55 / 48(52) \\
95 / 30(63) \\
95 / 60(75) \\
88 / 50(70) \\
85 / 40(52) \\
95 / 60(73) \\
56 / 34(45)\end{array}$ & $\begin{array}{l}3 \\
4 \\
2 \\
2 \\
4 \\
3 \\
4 \\
3 \\
2 \\
2 \\
1 \\
2 \\
1\end{array}$ & $\begin{array}{l}3 \\
4 \\
2 \\
2 \\
3 \\
2 \\
3 \\
4 \\
2 \\
1 \\
2 \\
2 \\
2\end{array}$ & $\begin{array}{l}3 \\
4 \\
2 \\
2 \\
3 \\
2 \\
4 \\
2 \\
2 \\
1 \\
1 \\
2 \\
3\end{array}$ & $\begin{array}{l}1 \\
1 \\
1 \\
3 \\
1 \\
1 \\
1 \\
4 \\
3 \\
3 \\
3 \\
2 \\
2 \\
2 \\
3\end{array}$ & $\begin{array}{r}10 \\
13 \\
7 \\
9 \\
11 \\
8 \\
15 \\
12 \\
9 \\
7 \\
6 \\
8 \\
9\end{array}$ & $\begin{array}{r}24 \\
11 \\
8 \\
118 \\
48 \\
8 \\
168 \\
49 \\
72 \\
6 \\
29 \\
5 \\
125\end{array}$ & $\begin{array}{l}\text { After } \\
\text { After } \\
\text { After } \\
\text { After } \\
\text { After } \\
\text { After } \\
\text { After } \\
\text { After } \\
\text { After } \\
\text { After } \\
\text { After } \\
\text { After } \\
\text { Before }\end{array}$ \\
\hline 14 & 3 & PDA & $70 / 30(50)$ & $\begin{array}{l}3 \\
1 \\
3\end{array}$ & $\begin{array}{l}3 \\
1 \\
3\end{array}$ & $\begin{array}{l}3 \\
3 \\
3\end{array}$ & $\begin{array}{l}3 \\
3 \\
3\end{array}$ & $\begin{array}{r}12 \\
8 \\
12\end{array}$ & 5 & $\begin{array}{l}\text { After } \\
\text { Before } \\
\text { After }\end{array}$ \\
\hline $\begin{array}{l}15 \\
16 \\
17 \\
18 \\
19 \\
20 \\
21 \\
22 \\
23 \\
24 \\
25 \\
26 \\
27 \\
28\end{array}$ & $\begin{array}{rr} & 10 \\
3 & \\
10 & \\
4 & \\
& 3 \\
& 10 \\
5, & 8 \\
1, & 9 \\
3 & \\
& 9 \\
1, & 5 \\
5 & \\
& 4 \\
2, & 11\end{array}$ & $\begin{array}{l}\text { VSD + PDA } \\
\text { VSD } \\
\text { VSD } \\
\text { VSD } \\
\text { VSD } \\
\text { VSD } \\
\text { VSD } \\
\text { VSD + PDA } \\
\text { PDA } \\
\text { PDA } \\
\text { ECD (III) } \\
\text { VSD } \\
\text { ECD (III) } \\
\text { VSD + PDA }\end{array}$ & $\begin{array}{r}50 / 13(34) \\
107 / 57(83) \\
110 / 65(82) \\
70 / 35(44) \\
55 / 20(35) \\
113 / 35(65) \\
90 / 53(67) \\
62 / 42(55) \\
24 / 9(15) \\
118 / 64(86) \\
74 / 20(48) \\
84 / 37(60) \\
60 / 10(40) \\
56 / 20(40)\end{array}$ & $\begin{array}{l}3 \\
4 \\
4 \\
3 \\
2 \\
3 \\
2 \\
3 \\
1 \\
2 \\
1 \\
1 \\
1 \\
1\end{array}$ & $\begin{array}{l}3 \\
3 \\
2 \\
2 \\
2 \\
3 \\
3 \\
4 \\
2 \\
2 \\
1 \\
1 \\
2 \\
1\end{array}$ & $\begin{array}{l}2 \\
3 \\
2 \\
2 \\
4 \\
3 \\
1 \\
4 \\
3 \\
2 \\
1 \\
2 \\
2 \\
2\end{array}$ & $\begin{array}{l}2 \\
1 \\
1 \\
1 \\
1 \\
2 \\
4 \\
3 \\
3 \\
3 \\
1 \\
1 \\
2 \\
1 \\
3 \\
2\end{array}$ & $\begin{array}{r}10 \\
11 \\
9 \\
8 \\
10 \\
16 \\
8 \\
14 \\
7 \\
7 \\
5 \\
5 \\
8 \\
6\end{array}$ & & $\begin{array}{l}\text { After } \\
\text { Necropsy } \\
\text { Necropsy } \\
\text { Necropsy } \\
\text { After } \\
\text { After } \\
\text { Necropsy } \\
\text { After. } \\
\text { After } \\
\text { After } \\
\text { Biopsy only } \\
\text { Biopsy only } \\
\text { Necropsy only } \\
\text { Necropsy only }\end{array}$ \\
\hline
\end{tabular}

VSD = ventricular septal defect; $P D A=$ patent ductus arteriosus; $E C D=$ endocardial cushion defect.

${ }^{*}$ For grading see text.

Table 2 Details of patients with congenital heart disease without Down's syndrome

\begin{tabular}{|c|c|c|c|c|c|c|c|c|c|}
\hline \multirow{2}{*}{$\begin{array}{l}\text { Case } \\
\text { No }\end{array}$} & \multirow{2}{*}{$\begin{array}{l}\text { Age } \\
\text { (years } \\
\text { and } \\
\text { months) }\end{array}$} & \multirow{2}{*}{$\begin{array}{l}\text { Cardiac } \\
\text { disease }\end{array}$} & \multirow{2}{*}{$\begin{array}{l}\text { Pulmonary } \\
\text { artery } \\
\text { pressure } \\
\text { (mean) } \\
\text { (mm Hg) }\end{array}$} & \multicolumn{4}{|l|}{ Grades* } & \multirow{2}{*}{$\begin{array}{l}\text { Histological } \\
\text { index } \dagger\end{array}$} & \multirow{2}{*}{$\begin{array}{l}\text { Duration of } \\
\text { artificial } \\
\text { respiration } \\
\text { (hours) }\end{array}$} \\
\hline & & & & $\begin{array}{l}\text { Interstitial } \\
\text { emphysema }\end{array}$ & $\begin{array}{l}\text { Overdistension } \\
\text { of air spaces }\end{array}$ & $\begin{array}{l}\text { Alveolar } \\
\text { hypoplasia }\end{array}$ & $\begin{array}{l}\text { Alveolar } \\
\text { septitis }\end{array}$ & & \\
\hline $\begin{array}{l}29 \\
30 \\
31\end{array}$ & $\begin{array}{ll}1 & \\
2, & 3 \\
1, & 4\end{array}$ & $\begin{array}{l}\text { VSD } \\
\text { PDA } \\
\text { VSD + PDA } \\
\quad+\text { ASD }\end{array}$ & $\begin{array}{r}55 / 28(39) \\
71 / 30(52) \\
104 / 56(72)\end{array}$ & $\begin{array}{l}2 \\
1 \\
4\end{array}$ & $\begin{array}{l}1 \\
1 \\
3\end{array}$ & $\begin{array}{l}1 \\
1 \\
2\end{array}$ & $\begin{array}{l}2 \\
1 \\
3\end{array}$ & $\begin{array}{r}6 \\
4 \\
12\end{array}$ & $\begin{array}{r}29 \\
5 \\
77\end{array}$ \\
\hline $\begin{array}{l}32 \\
33 \\
34 \\
35 \\
36 \\
37 \\
38 \\
39 \\
40 \\
41 \\
42 \\
43 \\
44 \\
45 \\
46 \\
47 \\
48 \\
49 \\
50 \\
51\end{array}$ & $\begin{array}{lr}2, & 4 \\
5 & \\
3, & 5 \\
8 \\
9 \\
1, \quad 4 \\
1,11 \\
6, \quad 8 \\
4 & 7 \\
4 & \\
& 3 \\
& 5 \\
& 3 \\
& 8 \\
4, & 8 \\
11 \\
1, & 2 \\
1, & 2 \\
1, & 2\end{array}$ & $\begin{array}{l}\text { VSD } \\
\text { VSD } \\
\text { PDA } \\
\text { VSD } \\
\text { VSD } \\
\text { VSD } \\
\text { VSD } \\
\text { PDA } \\
\text { VSD } \\
\text { VSD } \\
\text { VSD } \\
\text { VSD } \\
\text { VSD } \\
\text { TGA + VSD } \\
\text { TGA + VSD } \\
\text { TGA } \\
\text { TGA } \\
\text { TGA } \\
\text { TGA + VSD } \\
\text { TGA + VSD } \\
+ \text { + PS } \\
\text { TGA + VSD }\end{array}$ & $\begin{array}{r}83 / 30(56) \\
58 / 30(45) \\
50 / 30(40) \\
75 / 25(50) \\
80 / 32(54) \\
75 / 43(60) \\
76 / 28(52) \\
75 / 25(47) \\
98 / 45(70) \\
46 / 77(23) \\
73 / 15(38) \\
75 / 30(58) \\
80 / 40(60) \\
75 / 30(55) \\
110 / 70(85) \\
48 / 18(34) \\
40 / 25(30) \\
35 / 15(26) \\
100 / 60(80) \\
45 / 30(36)\end{array}$ & $\begin{array}{l}3 \\
1 \\
1 \\
1 \\
3 \\
3 \\
2 \\
1 \\
1 \\
1 \\
1 \\
2 \\
1 \\
2 \\
1 \\
1 \\
2 \\
1 \\
1 \\
1\end{array}$ & $\begin{array}{l}2 \\
1 \\
1 \\
1 \\
2 \\
1 \\
1 \\
2 \\
2 \\
2 \\
1 \\
1 \\
1 \\
2 \\
1 \\
1 \\
1 \\
1 \\
1 \\
1\end{array}$ & $\begin{array}{l}2 \\
1 \\
1 \\
1 \\
1 \\
1 \\
1 \\
1 \\
1 \\
2 \\
1 \\
1 \\
2 \\
1 \\
1 \\
1 \\
1 \\
1 \\
1 \\
1\end{array}$ & $\begin{array}{l}1 \\
3 \\
1 \\
1 \\
2 \\
2 \\
1 \\
1 \\
2 \\
1 \\
4 \\
1 \\
1 \\
1 \\
3 \\
1 \\
1 \\
4 \\
2 \\
3\end{array}$ & $\begin{array}{l}8 \\
6 \\
4 \\
4 \\
8 \\
7 \\
5 \\
5 \\
6 \\
6 \\
7 \\
5 \\
5 \\
6 \\
6 \\
4 \\
5 \\
7 \\
5 \\
6\end{array}$ & $\begin{array}{r}19 \\
7 \\
5 \\
5 \\
13 \\
43 \\
21 \\
5 \\
70 \\
29\end{array}$ \\
\hline
\end{tabular}

ASD = atrial septal defect; TGA = transposition of the great arteries; PS = pulmonary stenosis.

*For grading see text.

tIn all cases samples taken postoperatively. 
Down's syndrome and 23 of those without Down's syndrome had various degrees of pulmonary hypertension.

Lung biopsy specimens were generally taken after cardiac repair had been completed, but in two patients with Down's syndrome a biopsy specimen was also taken before the repair. Biopsy specimens were always taken from the anterior portion of the median lobe of the right lung when a median incision was made and from the lingula of the left lung when the approach was via the left thorax.

Both biopsy and necropsy specimens of lung were fixed in $10 \%$ formalin and embedded in paraffin. To examine the density of elastic and collagen fibres microscopic sections $3 \mu \mathrm{m}$ thick were stained not only with haematoxylin eosin but also with Goldner's trichrome combined with Weigert's stain for elastic fibres.

GRADING FOR HISTOPATHOLOGICAL CHANGES Interstitial emphysema-A four grade system was introduced to describe the severity of interstitial emphysema. Grade 1 denoted an absence of emphysematous change in the interlobular connective tissue; grade 2 mild emphysema; grade 3 moderate emphysema; and grade 4 severe emphysema, in which the connective tissue was completely destroyed (fig 1). All samples in which interlobular connective tissue was dissociated or disrupted by surgical procedures were excluded from the study.

Overdistension of peripheral air spaces-A four grade classification was also used for the degree of distension of the terminal air spaces. The normal state, in which no distension is seen, was designated grade 1; grade 2 denoted overinflation of alveoli; grade 3 denoted distension affecting alveolar ducts

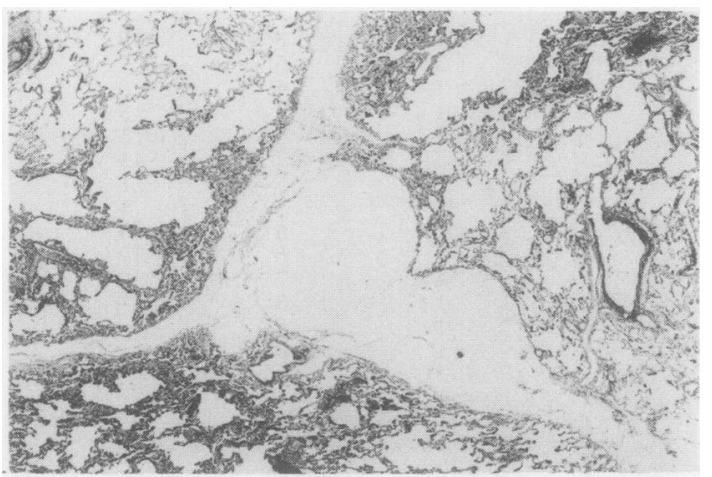

Fig 1 Interstitial emphysema in a patient with Down's syndrome (case 2). Interlobular connective tissue is completely destroyed (grade 4). (Elastica-Goldner stain $\times$ 4.) and sacs; and grade 4 referred to overdistension extending to respiratory brochioles (fig 2). Patients in whom distension of alveolar ducts was due to atelectasis in surrounding areas were excluded from the study.

Alveolar hypoplasia-Alveolar hypoplasia was classified according to its severity. Grade 1 denoted that the alveolar structure was sufficiently reinforced by entrance rings containing the normal quantity of elastic fibres (fig 3(a)). Mild deficiency of elastic fibres was classified as grade 2 and when the rings had only half the normal amount of fibres as grade 3 . Grade 4 corresponded to the state in which entrance rings had only a small number of elastic fibres (fig 3(b)).

Alveolar septitis-Ogawa et al found that in infants with a left to right cardiac shunt alveolar septa were thickened and infiltrated with lymphoid cells; they referred to this change as "septitis". ${ }^{2}$ Although its relation to other types of interstitial pneumonitis is not clear, this finding was encountered in our series, and we complied with their grading systemnamely, grade 1 for normal septa and grades 2, 3, and, 4 for mild, moderate, and severe septitis, respectively.

In each case the grade of pulmonary histopathological change was represented by summing the above grades, and this score was correlated with the severity of respiratory failure. As the evaluation of the degree to which a lung showed emphysema, overdistension, alveolar hypoplasia or septitis was non-parametric statistical analysis was done using the Mann Whitney U test.

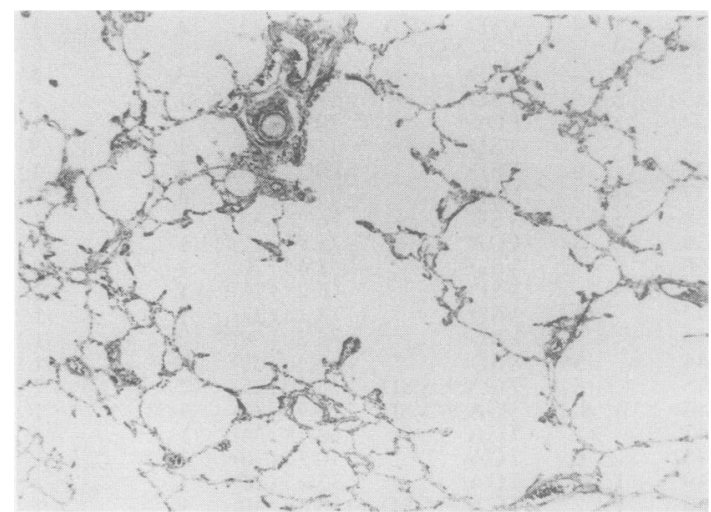

Fig 2 Overdistension of peripheral air spaces in a patient with Down's syndrome (case 8). Overdistension extends to respiratory bronchioles (grade 4). (Elastica-Goldner stain $\times 4$. 


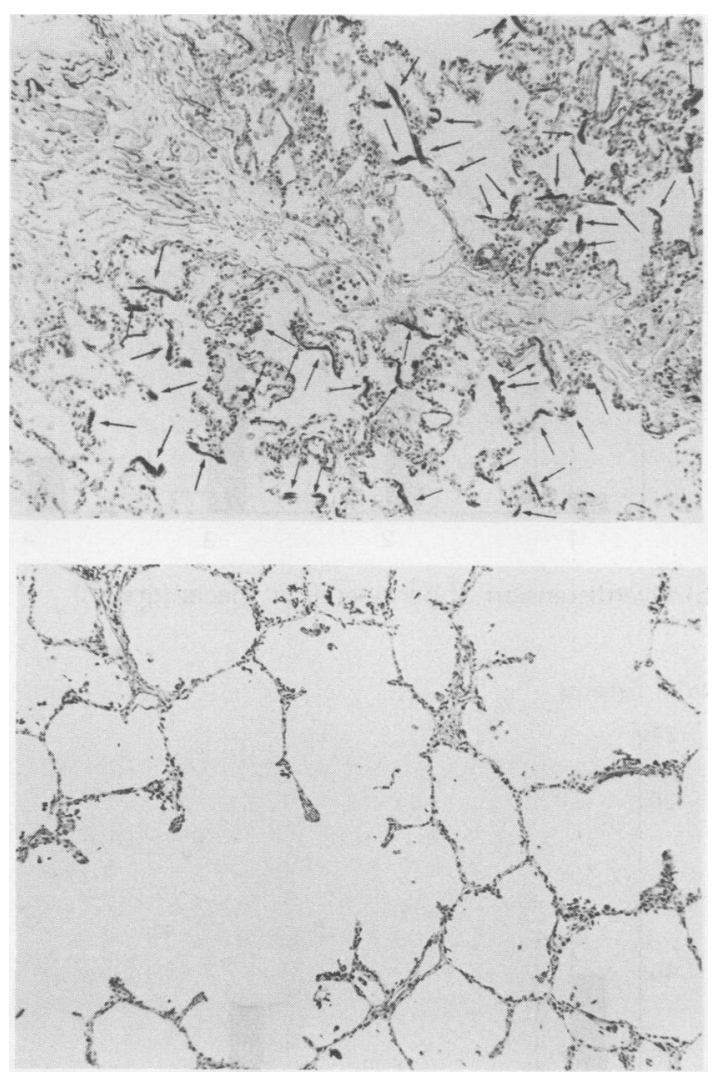

Fig 3 (a) Normal lung tissue in a patient without Down's syndrome (case 29), showing alveolar entrance rings rich in elastic fibres (arrows). No interstitial emphysema is present (grade 1). (Elastica-Goldner stain $\times 25$.) (b) Alveolar hypoplasia in a patient with Down's syndrome (case 7). Elastic fibres are deficient in the entrance rings (grade 4). (Elastica-Goldner stain $\times 25$.)

\section{Results}

Interstitial emphysema was found in $22(92 \%)$ of the 24 patients with Down's syndrome after cardiac repair (fig $4(a)$ ). Of these 22 , eight showed mild (grade 2), nine moderate (grade 3 ), and five severe (grade 4) emphysema. In contrast, only nine (38\%) of the 24 patients without Down's syndrome showed interstitial emphysema; five had grade 2 , three grade 3 , and one grade 4 . The total score was higher in the patients with Down's syndrome, with a significant difference by the Mann Whitney U test $(p<0.01)$.

Overdistension of peripheral air spaces was found in $23(96 \%)$ of the patients with Down's syndrome (fig 4(b)). The distension was restricted to alveoli (grade 2) in 11 patients, affected alveolar ducts and sacs (grade 3 ) in nine, and affected respiratory bronchioles (grade 4) in three. By contrast, overdistension of the lower air spaces was seen in only seven of the patients without Down's syndrome: six showing grade 2 and one grade 3 . Again, a significant difference between the groups with and without Down's syndrome was shown $(\mathrm{p}<0.01)$.

Alveolar hypoplasia was found in $21(88 \%)$ of the patients with Down's syndrome (fig 4(c)) including 10 with a mild deficiency of elastic fibres in the entrance rings (grade 2), seven in whom less than half the normal number of elastic fibres was present (grade 3), and four in whom fibres were almost completely missing (grade 4). On the other hand, of the 24 patients without Down's syndrome only four $(17 \%)$ showed mild deficiency (grade 2 ). The difference between the groups was significant $(p<0.01)$.

Alveolar septitis was found in 14 patients with Down's syndrome (58\%) (fig 4(d)). Four showed mild lesions (grade 2), eight moderate lesions (grade 3 ), and two severe lesions (grade 4). Alveolar septitis was equally common $(12(50 \%))$ in the patients without Down's syndrome, five showing grade 2, four grade 3 , and three grade 4 septitis.

In two patients with Down's syndrome (cases 13 and 14), in whom appreciable alveolar hypoplasia was present, interstitial emphysema and overdistension of air spaces were visible in specimens obtained just before the end of the operation, but no such changes were seen in samples taken immediately after thoracotomy. Moreover, in two patients subjected to thoracotomy for lung biopsy alone (cases 25 and 26) and in two examined post mortem without having undergone operation (cases 27 and 28) interstitial emphysema was absent and overdistension barely present in the presence of evident alveolar hypoplasia. Statistical analysis of the severity of pulmonary changes between the specimens taken after operation and those taken before operation or from lungs that did not undergo operation disclosed important postoperative deterioration in terms of the grade of emphysema and distension but without any sign of change in the grade of alveolar hypoplasia $(p<0.05)$.

In 14 patients with Down's syndrome and 13 without the grades of histological changes were correlated with the duration of artificial respiration (fig 5). It was found that in the patients with Down's syndrome the longer the duration of artificial respiration the higher the total histological grading scores. On the other hand, the patients without Down's syndrome not only had comparatively lower scores but showed a tendency towards a shorter duration of artificial respiration. The duration of artificial respiration in patients with patent ductus arteriosus was short for both groups except in one 
No of patients

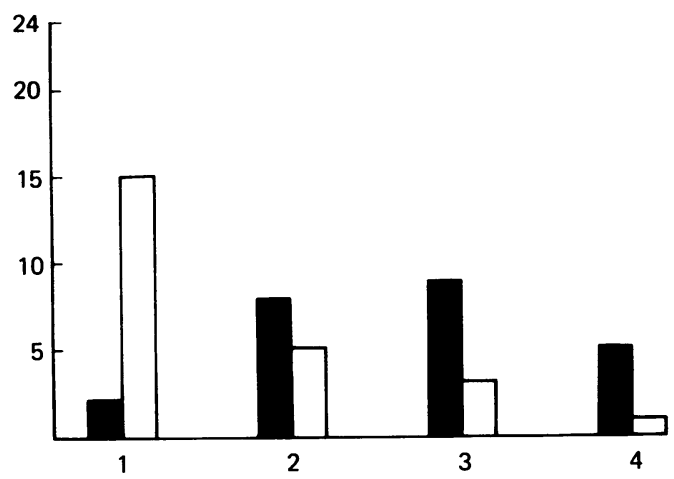

(a) Interstitial emphysema (grades)

No of patients

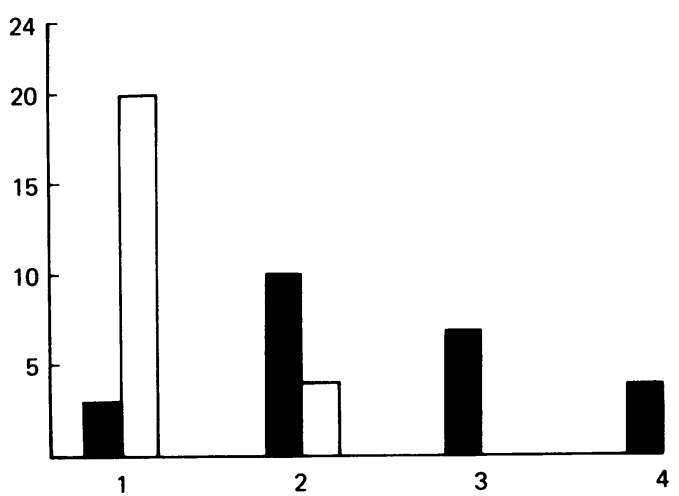

(c) Alveolar hypoplasia (grades)
No of patients

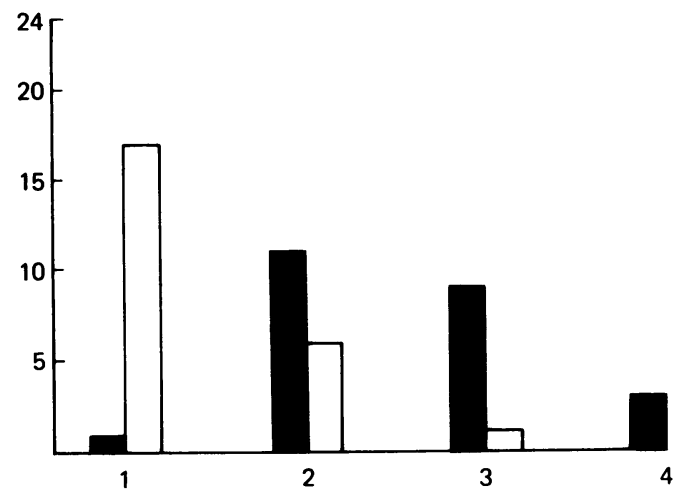

(b) Overdistension of peripheral air spaces (grades)

No of patients

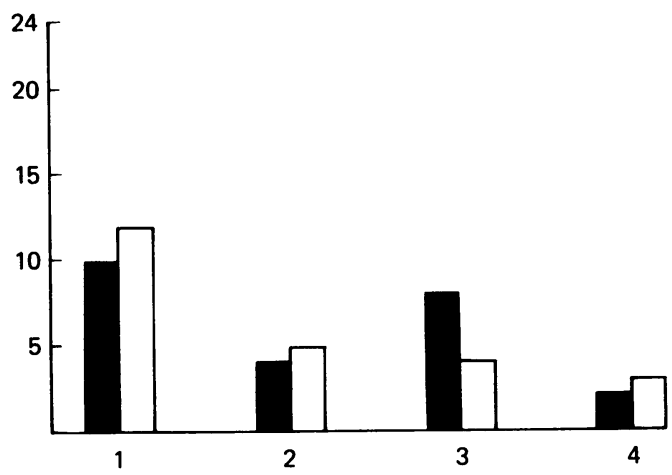

(d) Alveolar septitis (grades)

Fig 4 Grades of (a) interstitial emphysema, (b) overdistension of peripheral air spaces, (c) alveolar hypoplasia, and (d) alveolar septitis in patients with congenital heart disease with ( $\square$ ) and without ( $\square$ ) Down's syndrome.

patient with Down's syndrome who had stenosis of the trachea (case 7). In patients with either uncomplicated ventricular septal defect or ventricular septal defect combined with patent ductus arteriosus the duration of artificial respiration appeared to be longer the higher the histological score. A significant correlation was found between the duration of artificial respiration and the scores for histological change when the patients with and without Down's syndrome were combined $(p<0.01)$.

\section{Discussion}

Postoperative cardic and respiratory failure is often seen in patients with congenital heart disease and Down's syndrome. ${ }^{34}$ An important factor in the development of cardiac failure is postnatal pulmonary hypertension with pulmonary vascular disease $^{5-7}$ It has been suggested that respiratory failure is caused by pneumonia and other airway infections, ${ }^{3}$ but an underlying developmental abnormality of the lung tissue has not previously been reported. During the course of heart surgery in patients with Down's syndrome we had often found interstitial emphysema associated with increased airway pressure. This was considered to be responsible for the postoperative respiratory failure in such patients and led us to the present investigation of the lung tissue.

Interstitial emphysema, overdistension of distal 


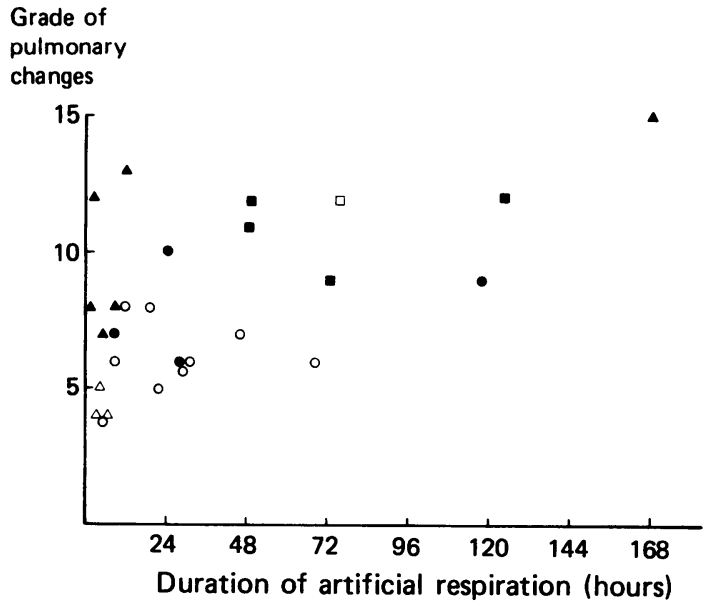

Fig 5 Correlation between duration of artificial respiration and grade of pulmonary change. Patent ductus arteriosus: with Down's syndrome $\Delta$; without Down's syndrome $\triangle$. Ventricular septal defect: with Down's syndrome ; without Down's syndrome $O$. Ventricular septal defect and patent ductus arteriosus: with Down's syndrome $\square$, without Down's syndrome $\square$.

air spaces, and alveolar hypoplasia were seen in most specimens taken after operation from lungs of patients with Down's syndrome but in only a small proportion of patients without Down's syndrome, and it seemed therefore that the lesion was specific. It is, however, necessary to establish whether this was really so or whether it was a product of the operation. A comparison of the specimens obtained by postoperative biopsy with those taken by preoperative biopsy or at necropsy in subjects who had not undergone surgery showed that the emphysema and overdistension that were almost always found in the lungs after operation were minimal or absent in those who had not undergone surgery. Alveolar hypoplasia, however, was a constant finding whether the specimen was taken before or after cardiac repair. This suggests that in patients with Down's syndrome there are varying degrees of congenital alveolar hypoplasia characterised by a deficiency of elastic fibres in the entrance rings of alveoli. In normal lungs these fibres are likely to play a definite part in maintaining normal alveolar structure. As airway pressure increases during surgery in patients with Down's syndrome overdistension of alveoli, alveolar ducts and sacs, and even respiratory bronchioles may lead to rupture of the poorly reinforced air spaces and subsequently to interstitial emphysema.

Cooney and Thurlbeck reported that in a mor- phometric analysis of lung tissue of patients with Down's syndrome the number of alveoli contained in a lobule was smaller than normal. ${ }^{8}$ As none of the lungs used in our study was infused intrabronchially with formalin but all were simply fixed in various states of collapse quantitative aspects of airway architecture were not investigated. It appears to be of fundamental importance, however, in understanding the peculiar lung function in Down's syndrome to examine in some future morphometric studies whether our results are substantiated by coexisting signs of retarded development of architecture, such as a decreased number of alveoli or reduction in airway branching, or both. Such an attempt should also include some parametric expression of the degree to which the entrance rings of alveoli are deficient in elastic fibres.

Ogawa et al emphasise alveolar septitis as a causative factor in postoperative respiratory failure of infants and attributed this change to repeated infection of airways. ${ }^{2}$ In our study mild to moderate change in alveolar septa, comparable to their description, was occasionally found in patients with or without Down's syndrome, but there was no difference between the groups in its incidence or severity.

Various factors contribute to respiratory failure after cardiac surgery, including the surgical stress inevitably associated with thoracotomy, anaesthesia, and extracorporeal circulation. Because the duration of artificial respiration seems to be the most reliable index of the severity of postoperative respiratory failure we correlated the duration of artificial respiration with the grades of histological changes in the lung. To make this correlation meaningful it was necessary to prevent the results from being influenced by other factors, and for this reason we selected patients over the age of 6 months with simple cardiac anomalies and pulmonary hypertension who underwent total correction. A correlation was shown between the duration of artificial respiration and the severity of pulmonary lesions when the patients with and without Down's syndrome were pooled.

We conclude that interstitial emphysema, overdistension of air spaces, alveolar hypoplasia, and septitis all play a part in the development of postoperative respiratory disturbance. In the surgical treatment of congenital heart disease, especially when associated with Down's syndrome, it appears to be imperative to take special measures to keep airway pressure as low as possible during anaesthesia to prevent rupture of peripheral air spaces and the development of interstitial emphysema, which is one of the major hazards of the surgical repair of cardiac disease in such patients. 


\section{References}

1 Thurlbeck WM. Postnatal human lung growth. Thorax 1982;37:564-71.

2 Ogawa $\mathrm{K}$, Ito $\mathrm{H}$, Toriyama $\mathrm{A}$, et al. Lung patholgy in infants with severe pulmonary hypertension and cardiac disease. J Thorac Cardiovasc Surg 1979;77:728-32.

3 Shaher RM, Farina MA, Rorter IH, Bishop M. Clinical aspects of congenital heart disease in Mongolism. Am J Cardiol 1972;29:497-503.

4 Greenwood RD, Nadas AS. The clinical course of cardiac disease in Down's syndrome. Pediatrics 1976;58:893-7.

5 Chi TPL, Krovetz LJ. The pulmonary vascular bed in children with Down's syndrome. J Pediatr 1975;86:533-8.

6 Yamaki S, Horiuchi T, Sekino Y. Quantitative analysis of pulmonary vascular disease in simple cardiac anomalies with the Down syndrome. Am J Cardiol 1983;51:1502-6.

7 Noonan JA, Watters LR. Hemodynamic studies in Down's syndrome patients with congenital heart disease [abstract]. Pediatr Res 1974;8:353.

8 Cooney TP, Thurlbeck WM. Pulmonary hypoplasia in Down's syndrome. New Engl J Med 1982;307:1170-3.

9 Emery JL, Mithal A. The number of alveoli in the terminal respiratory unit of man during late intrauterine life and childhood. Arch Dis Child 1960;35:544-7. 